Bourdieu, Capital and Conflict in a Religious Field: the Case of the Anglican Communion

\author{
Andrew M McKinnon \\ Marta Trzebiatowska \\ Christopher Craig Brittain \\ University of Aberdeen
}

To be published in The Journal of Contemporary Religion 2011, vol 26, no. 3, pp. 355-370.

For the definitive final text version, please go to:

http://www.tandfonline.com/doi/abs/10.1080/13537903.2011.616033\#.VBxFPPldU1I

\begin{abstract}
Although Bourdieu's sociological project is a generalised sociology of religion, his work has not been as influential among sociologists of religion as one might have expected it to be. In this paper we provide an overview of Bourdieu's analysis of religion, paying particular attention to key problems that have been identified in the literature, and suggesting how his work can be understood in such a way as to overcome these limitations. Drawing upon research by two of the authors of this current paper, we show how Bourdieu's sociology is helpful for understanding the conflicts over sexuality in the Anglican Communion.
\end{abstract}

\title{
Introduction
}

Given that the work of Pierre Bourdieu has been so influential in many other subfields of sociology — in particular the study of art, culture, and education, where symbols and symbolic manipulation are central — it is somewhat surprising that it has had so little impact on the sociology of religion. This is all the more astonishing since Bourdieu's sociology can be understood as a 'generalised' sociology of religion (Dianteill 530); indeed, many of Bourdieu's key concepts, most obviously the conceptions of consecration, belief and habitus, but also his notion of 'field', come from his encounter with the sociology of religion, 
especially from Weber's work on religion, but also that of Durkheim on the sacred and profane and Mauss on embodied practices.

Bourdieu's work has attracted some attention from sociologists of religion (Swartz, Dillon, Dianteill, Verter, Flanagan), though it has been the stimulus for relatively little empirical sociological research on religion (but see Berlinerblau, Wood and Bunn). For the most part, enthusiasm from sociologists of religion has been noticeably muted. Although recognising much of Bourdieu's thinking as directly relevant for the sociological consideration of religion, several related criticisms seem to pose a problem for the broader adoption of Bourdieu's conceptual rubric by sociologists of religion. These complaints include the suggestion that Bourdieu's sociology of religion is too French and too Catholic, and this limits its applicability to the study of other religious traditions and contexts. Secondly, numerous observers have argued that Bourdieu's conception of religion is too rigidly structured to adequately comprehend contemporary fluid religious realities.

In this paper, we begin with a general and brief synopsis of Bourdieu's conceptual apparatus, followed by a review of the criticisms outlined above. We propose that, although there is considerable truth to these criticisms, the logic of Bourdieu's sociology of religion can readily address the concerns expressed. We elaborate on Bourdieu's concept of fields, showing that religious fields, like other forms of social field, will be different in different times and places, and that a Bourdieusian sociology of religion, rather than simply applying his writings that are implicitly about French Catholicism to other situations, must take into account the particularities of the field being considered. In particular, we suggest that the monopoly of religious capital is not as effective within religious fields as Bourdieu seems to assume it is in his writings on religion. Finally, we argue that the religious field must be considered not only as national, but also transnational, as well as local or denominational. Moreover, these different fields are best understood as nested within one another. 
In expounding and expanding Bourdieu's conception of religious fields, in the second part of this paper we draw on empirical research by two of us on the current conflict over sexuality in the global Anglican Communion (references withheld). As part of a broader project, two of the co-authors of the present paper have 43 interviews in Britain and North America, including 16 with bishops, and 27 with clergy, activists on both sides of the issue, as well as other involved laypeople; in the latter we, focused primarily on two North American dioceses where the conflict has been particularly intense. This paper draws on our ongoing research, but particularly on our interviews with Anglican bishops and primates, as they have been in the best position to observe the conflict at the highest levels.

Bourdieu's writings on religion may reflect a Republican analysis of a French national-catholic religious field the basic logic of his sociological inquiries remains useful. Once Bourdieu's theory of religious fields is corrected of its methodological nationalism (both its Franco-catholic, and its nation-state-bounded assumptions) it provides a useful lens for looking at the Anglican dispute, its causes and consequences. The conflict itself highlights that the experiences of actors in local and national religious social fields only make sense when they are considered in conjunction with the transnational religious fields in which particular national and local religious fields are embedded.

\section{Bourdieu's Sociology of Religion}

The Holy Trinity of concepts which largely frame Bourdieu's analysis of society are: field, capital and habitus. These concepts, and the relation between them, developed as Bourdieu sketched out his sociology of religion, but he has applied them, (with regular modification updating and adaptation) to a variety of topics, including art and culture, the academy, education, politics, and the economy. 
A field is a metaphor that plays on the notions of force field, as well as battle-field. Bourdieu's concept of a "field" (champ) is complex and one, and he was always reticent to provide a "professorial definition" of it (Bourdieu and Wacquant, "Invitation" 95). Loïc Wacquant provides a reasonably concise summation of the idea of a "field" in a book coauthored with Bourdieu. Wacquant writes:

A field is simultaneously a space of conflict and competition, the analogy here being with a battlefield, in which participants vie to establish monopoly over the species of capital effective in it — cultural authority in the artistic field, scientific authority in the scientific field, sacerdotal authority in the religious field, and so forth — and the power to decree the hierarchy and "conversion rates" between all forms of authority in the field of power. In the course of these struggles, the very shape and divisions of the field become a central stake, because to alter the distribution and relative weight of forms of capital is tantamount to modifying the structure of the field ("Invitation" 1718).

The structure of any given field is the product of its history, in which previous struggles have resulted in a particular constitution of that field, and the established value of particular kinds of capital.

When discussing the economic field, Bourdieu means the same thing Marx did by the term 'capital'. What counts as capital, however, is specific to particular fields. Fields are defined by the forms of capital that are pertinent to that field: economic capital in the economic field, scientific capital in the academy, cultural capital in the field of cultural production, and so forth. In non-economic fields, capital is understood metaphorically, as playing the same role in that particular field as economic capital plays in the economic field. The one is not reducible to the other, however. In the artistic field, as Bourdieu argues, that which is economically successful is not likely to be seen as artistically successful, as 
exemplified by the divergence of 'critical acclaim' and 'economic success'. At least until recently, with the rise of the business-orientated Modern Art superstars (Andy Warhol, Damien Hirst, Jeff Koons), to be a commercial success was unlikely to garner artistic capital —it would be seen, within that field, as not real (or serious) art, but rather, as crass commercialism.

The positions in every field are hierarchical because capital cannot be evenly distributed. While the stakes and particular forms of struggle will be different in different fields, for Bourdieu capital is always a resource (symbolic or material) that can be used to maintain or improve one's position in a given field. The current shape of any given field will largely reflect the history of struggles in that field for particular forms of capital (Swartz 7981). Agents and institutions deploy strategies in their attempts to gain and maintain control of a field's capital, and these struggles shape and reshape the basic dimensions of the field.

Actors are situated in structured social fields, and endowed with differing amounts of capital, but they act largely on the basis of their habitus, described by Bourdieu as 'a lasting, generalised and transposable disposition to act in conformity with a (quasi-) systematic view of the world and human existence' ("Legitimation" 126). Bourdieu typically refers to the habitus as a 'structuring structure': it is both the matrix of perception for the actor and his or her 'feel for the game', a set of skills and dispositions for playing the game with the amount of capital at their disposal. Strategies are seldom fully conscious, and are informed by the objective positions of the agents in the field. The positions, in turn, depend on the amount and relative value of the capital with which agents are equipped.

Bourdieu wrote relatively little about the religious field per se, and the most extensive discussions are found in two essays of the early 1970s ("La dissolution", "Genesis"), as well as in several occasional pieces from the 1980s ("Sociologues de la croyance", “Legitimation"). In the major essays, which are largely an exegesis of Weber's sociology of 
religion, Bourdieu argues that we can only speak of the religious field with the emergence of an organised body of religious professionals. Sociologists have long recognized the social process of differentiation between social spheres, and this is an important dimension of Bourdieu's sociology of religion. 'Religion' is not something that has existed from time immemorial, but rather something that emerges with the development of a distinctive field, with its own particular form of capital, and a professional body who control and distribute the 'goods of salvation' (“La dissolution”).

The religious field gains relative autonomy when religious specialists monopolise religious knowledge to the exclusion and dispossession of the laity. This, Bourdieu argues, is the origin of the distinction between sacred and profane: the secular and ignorant (profane) are symbolically separated from those who have access to religious capital (sacred). The symbolic separation is maintained and reinforced successfully only if the priestly body disguises their worldly (political) interests and the lay people misrecognise the objective nature of the priestly monopoly over the goods of salvation (“Genesis").

Bradford Verter, who has criticized Bourdieu's relative inattention to the interconnection between various fields, suggests that Bourdieu treats fields as an archipelago of islands, each being separate from, and largely independent of the others (162). Bourdieu has always argued that the relation between fields was an "extremely complex" question that he was reluctant to try to answer, in part because of his distaste for the rigid schemas of the grand theorists and models that provide answers rather than relevant questions for empirical research. "I blame most of my readers for having considered as theoretical treatises," Bourdieu explains, "works that, like gymnastic handbooks, were intended for exercise, or even better, for being put into practice" (in Karakayali 359). He was reticent to schematize these relations precisely because they are contingent, the products of struggle, and because, as a result, the relations between fields changes ("Invitation" 109). Verter reconceives fields and 
their inter-relations as circles in Venn diagrams; this is a potentially fruitful intervention in this under-specified area of Bourdieu's work, but it also poses a certain analytic risk. Bourdieu does sometimes suggest that particular fields overlap, or even dissolve into one another (a), but he consistently argues that the borders of fields are always a stake in the contest of the field itself. Each field has "admission fees" that they exact from those who enter the field ("Invitation" 94-115). To conceptualise the relation between fields as overlapping circles in a Venn diagram is to fail to problematise the points where such fields meet, and sometimes overlap, as contested, and always political.

Religion has increasingly become differentiated not only from the state, but the economic field, the educational field, the cultural field, and so forth, each having its own kind of capital. These forms of capital may be exchangeable for religious capital, but the rate of conversion between capitals from different fields is historically contingent. Thus, the recognition of certain forms of educational capital (but not others) as legitimate or even necessary for admission to a position of influence within the religious field is a product of the history of power relations in which certain forms of educational capital (such as theology degrees granted by particular institutions) have been recognised, and the value of this capital shapes the field in an ongoing way. Likewise, religious capital may be important for entry into other fields - in some countries, for example, a certain amount of religious capital may be necessary for entry into the political field, though in others, it may prove to be a political liability (US v. Britain).

In his writings on religion, Bourdieu conceives of the religious field as having relative autonomy from the political field. In fact, the only way an enduring monopoly over the goods of salvation can be achieved, Bourdieu argues, is through the operation of a bureaucratic apparatus, which carries out a continuous, ordinary routine, and if this monopoly is, at least tacitly, supported by state power (Rey). The church maintains, as a matter of dogma, its 
exclusive right to the monopoly over access to salvation-extra ecclesiam nulla salus (there is no salvation outside the church). Within the church, the priesthood maintains a sacerdotal monopoly, as the designated and exclusive authority for the administration of the sacraments (the eucharist, baptism, reconciliation, confirmation, marriage, and ordination). Lay consumers are dispossessed of religious capital, and thereby inculcated with a particular religious habitus. The laity possesses enough capital to articulate their religious needs, but not enough to become players in the struggle over monopoly and legitimacy. The excluded typically misrecognise 'the arbitrariness of the monopolisation of a power in principle accessible to anyone' (“Genesis” 25). As religion is rationalised and systematised by being performed by trained professionals, lay people are kept at a distance and come to believe they do not have the gift of grace necessary to perform the activities of the clerics. Bourdieu's views on this have, quite evidently been shaped by his observations of the monopolising tendencies in French Catholicism, and some have called into question the applicability of his thinking on these matters in other contexts.

\section{Re-considering fields}

In the English-language preface to Distinction, Bourdieu warns against hastily drawing comparisons between different national cultural fields and the way that they organise stratification — 'Is Brigitte Bardot like Marilyn Monroe?' (xii). Nonetheless, he argues, the principles and concepts on which his analysis of the particular French system is based should be translatable from one situation into another. A similar caution ought to apply to Bourdieu's rather more fragmentary corpus of writings on religion, and the way in which it is translatable into religious fields with different structures, structures that have emerged from a history of different struggles. The religious field 'must not be conceived of as an immutable 
reality: a structural genesis exists for it in relation to transformations of social structure' (Dianteill 544).

As Erwan Dianteill observes, 'Bourdieu's sociology of religion is, first and foremost, a sociology of [French] Catholicism. The accent thus falls on the process of monopolization by a single institution: the Catholic Church' (535). Bourdieu's sociological analysis of religious monopolisation and fits neatly with the dominant tendency of French sociology, as a Republican discipline, an inclination which continued long after the French Catholic church lost its state sponsored monopoly status in 1905 (545), and even after the Catholic Church officially gave up its claims to monopoly at Vatican II (1962-65), admittedly with resistance from the French Episcopate (cf. Wilde).

Sociologists of religion outside of France have expressed concern about the particularistic aspects of Bourdieu's sociology of religion, although not necessarily recognising the structure of the (French) situation which gave rise to them. Bradford Verter argues that the only way to make use of Bourdieu's sociology of religion is by turning away from his explicit writings on religion, and using the tools drawn from his studies of other fields. Bourdieu's writings on the sociology of religion embody a model that is 'too rigid to account for the fluidities of today's spiritual marketplace' (Verter 151), by which Verter means, above all, an American spiritual marketplace. Verter further argues that Bourdieu's 'Voltairean' image of the Roman Catholic Church, 'leaves little room for imagining laypeople as social actors capable, for example, of manipulating religious symbols on their own behalf' (Verter 151).

Pursuing the same lines of thought, Michele Dillon argues that Bourdieu's sociology of Catholicism is inadequate for understanding American Catholicism. In her study of the Women's Ordination Conference, she found that, contrary to Bourdieu's explicit statements, the laity are not entirely dispossessed of religious capital, but interpret Catholic doctrine as a 
way of arguing with the hierarchy's unswerving opposition to the ordination of women. The laity, Dillon suggests often are producers and manipulators, rather than mere passive consumers, of religious symbols. According to Dillon, Bourdieu understates 'the ways in which people actively construct meaning in their everyday practices and how these new or reinterpreted cultural schemas may foster social change' (412). In American Catholicism, the church's monopoly is far from total because, unlike in some European countries, it operates as a denomination.

Religious fields are not immutable, and will differ by national context, as each has a different history. Bourdieu's writing on religion either took a particular time and place (postwar France) as an implicit background (as in his reflections on Weber), or as the site of his research (Bourdieu and St Martin). The general principles of Bourdieu's sociology in fact demand that, since the structure of positions and the value of different forms of capital are the product of the history of struggle, one must take into account the different structures of religious fields.

David Martin's typology of different types of national religious situations (Martin), and the way that these situations result in different trajectories of secularisation, is useful for thinking about the different ways that religious fields may be organised. As several different commentators have noted (Swartz, Verter, Dianteill, Dillon) Bourdieu's religious field is one in which a single church has a monopoly on the production and distribution of salvation-extra ecclesiam nulla salus. Bourdieu's explicit model needs revision if it is to prove analytically sufficient to religious fields on a continuum from American pluralism to monopolised religious fields like we find in Orthodox, or Latin Catholic, religious fields.

The basic structure of any field is the outcome of previous struggles over the structure of that field. As a result, we would expect, following Bourdieu's own logic, that different religious fields are structured in quite different ways. Recall that Martin argues that the 
process of secularisation happens quite differently in different places because of the basic structure of what Bourdieu would call the religious field, and in particular the relationship between the religious field and the state. Bourdieu's explicit model, with a single church that has managed to achieve a monopoly of the production of salvation fits best with the frames that Martin identifies as the Latin Catholic model (of which France is a prototype), but even better with Nationalist Catholic religious fields, such as one finds in Poland, and with those societies with an Orthodox monopoly (Greece, Russia, Romania, etc.).

A further weakness of Bourdieu's work, as it is usually construed, is its implicit methodological nationalism. This entails Bourdieu's use of French society as the model for all somewhat different kinds of religious fields, but also the way he tends to treat fields. Whether they are cultural, academic, educational or religious, fields are generally treated in Bourdieu's work, as coterminous with the nation state. This is for the most part a matter of emphasis: Bourdieu does not treat fields as hermetically sealed, and in his writings on the academic field, for example, he has recognised the import of imported ideas as local intellectual capital, and in his political writings, he has certainly given due attention to international political and economic fields (“Acts", "Cunning"). Given the centrality of the nation state in modernity, and the way that states regulate, legislate, fund and administer various social fields within their territorial boundaries, to conceive of fields in predominantly national terms is sensible. However, we argue that it is important to conceive transnational and local religious fields along with national religious fields as inter-related social fields, indeed as nested fields within which lower levels have sometimes considerable autonomy from the field in which they are embedded.

Scholarship on migration has begun to employ the notion of the transnational social field (Levitt and Schiller), in broadly Bourdieusian terms. Migration has highlighted the transnational dimension of much of contemporary religious life (Levitt); the organisation of 
much of religious life is inherently transnational, whether one is talking about migrants, transnational communities like the Islamic Umma (Roy), global networks of Pentecostal Christians, and some religious organizations are very nearly global in their scope, such as the Roman Catholic Church, or the Anglican Communion.

This suggests the need to re-conceive religious fields not only as structurally different in diverse contexts each with its own history, but also to consider the way that national religious fields are embedded in transnational religious fields. These may structure national and local religious fields (by means of colonialism, transnational religious organisations, for example) but also provide new arenas for conflict and collaboration between international actors, as well as between actors within national and local religious fields.

Reconceiving religious fields as both national and transnational, but also allowing for religious fields that are not so effectively monopolistic as in Bourdieu's writings on religion, Bourdieu's sociology provides a useful lens for making sense of the symbolic politics and dynamics of intra-religious conflict. Religious fields are indeed fields of contest, but they are precisely so because religious capital is not always, or only, taken for granted.

\section{The Anglican 'Homosexuality' Conflict: International and National Religious Fields}

Since the middle of the 1990s, the Anglican Communion has been caught up in an increasingly intense conflict over homosexuality in the church, with particular focus on the legitimacy of blessing same-sex unions, and gay clergy and gay bishops. In 1998, the decennial conference of Anglican Bishops worldwide, the Lambeth conference, was the site of a heated debate between advocates for greater inclusion of homosexuals and those who see any form of homosexual practice as sinful, and therefore to be excluded from the church. The actors in the conflict included the bishops who had gathered from the four corners of the earth, and who constituted the official delegates of the conference, as well as representatives 
from para-church organisations with a stake in this issue. Perhaps the most memorable scene, played over and over again in the news, and often taken as an exemplar for understanding the conflict, was a shouting match between Bishop Emmanuel Chukwuma, of Enugu, Nigeria, and the Reverend Richard Kirker, a leader in the Lesbian and Gay Christian Movement. As the scene unfolded in front of stunned Episcopal colleagues and a small army of reporters, Bishop Chukwuma tried, in an act that Bourdieu would identify as 'symbolic violence', to exorcise a 'demon of homosexuality' from the Reverend Kirker.

Lambeth 1998 resulted in Resolution 1.10, which can be seen in some respects as a compromise resolution supported by the very large moderate middle, even if it has done little to quell the conflict; since it left both sides feeling profoundly dissatisfied, may even have intensified it. Resolution 1.10, identifies 'homosexual practice as incompatible with scripture' while also 'call[ing] on all our people to minister pastorally and sensitively to all irrespective of sexual orientation and to condemn irrational fear of homosexuals'. In an alternate amendment, 'irrational fear of homosexuals' had read 'homophobia', but this did not prove to have sufficient support from the floor. In practical terms, Lambeth 1.10 states that the bishops 'cannot advise the legitimising or blessing of same sex unions nor ordaining those involved in same-gender unions', which is far from an unequivocal condemnation. The final clause of the resolution 'recognised the significance' of (but did not endorse) the Kuala Lampur Statement on Sexuality (representing a hard-line conservative position sponsored by largely Third World bishops). ${ }^{1}$

Because of the structure of the Anglican Communion, resolutions made Lambeth are not binding on the individual Provinces (predominantly national churches). Each has its own history, and although the episcopacy is a defining feature of Anglicanism, the structures of power can be quite different from province to province, including the way that bishops are selected, and the rules that could be used to depose them. The Anglican Communion is, unlike 
the Roman Catholic Church, a relatively loosely structured collection of dioceses, organised into provinces and held together, at least in theory, by four 'instruments of unity': the Archbishop of Canterbury, the Lambeth Conference (which includes all bishops, at the invitation of Canterbury), the Primates meetings (the head of each province), and the Anglican Consultative Committee, which has representatives from each of the houses (laity, clergy, and bishops) from each province. How, and currently, even if these provide for the unity of the church is another question, especially since none has binding power over any province (and provinces are limited by canon law in their exercise of authority over individual bishops). Currently an 'Anglican Covenant' is being mooted as a fifth instrument of unity, and there are heated discussions about whether it would have binding powers on member provinces, and what those would be. For the Covenant to be binding, the canon laws of each province would have to be changed, and it seems unlikely that most provinces will be keen to give up their autonomy.

The past ten years have seen the conflict escalate to the point where many have begun to talk about a schism within the Anglican Communion; one of the bishops we interviewed after Lambeth 2008 declared the Communion 'already dead' (Bishop James ${ }^{2}$ ). Such is the ongoing division that 280 bishops boycotted the Lambeth 2008 meetings, holding their own meeting in Jerusalem the month before, calling itself the Global Anglican Futures Conference (GAFCON). As interview subjects from a variety of perspectives repeated again and again, homosexuality is a 'presenting symptom' for a broader conflict—what the meaning of the real issues are, however, is a matter of deep disagreement.

The conflict within The Episcopal Church (USA), and to a slightly lesser degree within the Anglican Church of Canada, has been more intense than it has within any of the other Provinces of the Anglican Communion. The conflict arguably began in earnest, in the USA, in 1989-1990, with the ordination by Bishops Spong and Righter, of openly gay priests. 
Although the moderate mainstream within The Episcopal Church was broadly sympathetic to the ordination of gay priests, it was also aware that this was a potentially divisive issue, coming shortly on the heels of controversy over women in the priesthood and episcopate. For conservative Anglo-Catholics, who had been opposed to the ordination of women priests, these ordinations were a declaration of war; the most conservative Evangelicals had long been 'itching for a fight' (Bishop David). In the year 2000, Anglican churches in Africa and South Asia began ordaining 'missionary bishops' to the United States, arguing that the liberal Episcopal Church had forfeited its right to be seen as a legitimate Anglican, or even Christian, church, an act which would have, not very long ago, been seen as entirely illigitmate, an 'incursion' on the authority of an Episcopal colleague (Hassettt 132ff).. The archbishops sending such missionary bishops, however, had clearly come to the conclusion that the 'revisionist' bishops had lost their legitimate authority. Dissident conservative parishes then felt they had an option of remaining Anglican while declaring their independence from a 'liberal' bishop and the 'corrupt' or 'unchristian' Episcopal Church.

In the Anglican Church of Canada, conflict centred primarily around the Diocese of New Westminster, where, in 1998, the diocesan synod had voted to perform public rites of blessing for same sex couples. Although the Bishop of New Westminster, Michael Ingham, had withheld his consent until 2002 when a motion in support of such blessings had passed for a third time in the Diocesan Synod, he was often treated, especially by conservatives within his own diocese, as an aggressive advocate of liberalism and gay rights, positions that local conservatives see as unchristian and incompatible with the dictates of Scripture.

One could treat the conflicts within The Episcopal Church and the Anglican Church of Canada as intra-national conflicts, making them broadly comparable with the kind of disagreements often studied by sociologists of religion (Ammerman, Kniss, Chaves) where intra-denominational religious conflict is primarily also intra-national denominational 
conflict, the borders of the religious organisation largely being coterminous with that of the national state. However, the conflict over homosexuality in the Anglican Communion highlights the ways in which national religious fields may be embedded in transnational religious fields. The conflict is transnational in large measure because the Anglican Communion is itself a transnational network, with structurally integrated, yet autonomous (national) Provinces.

Philip Jenkins has argued that the conflict in the Anglican Communion can be primarily understood as the result of a demographic shift in the balance of the Anglican Communion, between a shrinking liberal Church in the North, and a growing, Conservative church in the South. It is easy to overstate the degree to which the conflict over sexuality is an inter-provincial (transnational) conflict, rather than one which is also intra-provincial, however. Indeed, while the Anglican Church of Nigeria, for example, speaks with one voice, usually that of the Primate, the polity of that Anglican Church in Nigeria is such that the Primate has significant power for enforcing the party line-including the ability to fire Bishops who dissent from it (Bishops Timothy, Mark and David). This would simply not be possible in the Church of England and or in many other provinces; the powers of the Primate are particularly circumscribed in The Episcopal Church, USA (Bishop Mathew). Diversity of opinion among the Nigerian Episcopate, and the Anglican Church of Nigeria as a whole, is carefully and effectively hidden from view (Activist interview 1, Bishop Kevin). The situation is far different in North America, however, where some dioceses in the Episcopal Church and the Anglican Church of Canada are openly and deeply divided on the question of homosexuality. Miranda Hassett has argued that the conflict is better seen as a result of conservative Episcopalians in the USA organizing networks of dissent against the liberal Episcopal establishment, and enlisting the help of international actors, typically conservative bishops from other Provinces. Stephen Bates concurs although he gives more credit to the 
long established organizational networks of Evangelical organizations within the Church of England.

Conservative activists in North America have typically highlighted the importance of their international connections in their fight with, and attempt to reform or separate from, a church that they see as corrupted by apostasy. One influential activist, comparing the situation of dissident Anglicans to the position conservatives in other mainline denominations stated flatly that without the aid of foreign bishops, their movement would have quickly floundered: we 'would have been sunk, and would have had to just leave the Anglican Church' (North America Interview 5).

Until recently, the concept of the historic episcopate was seen as binding — a bishop was the legitimate authority in a diocese because he (or more recently, and in only in some provinces, she) had been appointed by the canonical process, taken the right vows and been anointed by other bishops. Bishops thus elevated embodied an unbroken line of authority stretching back to St. Peter and the Apostles. If you didn't like your bishop (and this has no doubt long been less than uncommon), you kept your head down and prayed the next one would be better. An Episcopal see was thus the most important form of Anglican capital that could be accrued. Significantly, this capital alone confers the right to ordain priests, and to authorise them for work in a particular diocese. Only priests ordained and licensed by a legitimate bishop may preside over Holy Communion in an Anglican church, and only by rites authorised by the diocesan bishop.

The ability to reach beyond diocesan and provincial borders to sympathetic senior leaders in the African, Asian, South American and British churches has provided a means for dissident North American conservatives to stake their claim to being the only truly legitimate Anglicans. Although bishops are, by definition, bishops of a diocese (geographically demarcated) the support of, and recognition by foreign bishops has provided them with 
important sources of religious capital for use in their local and national struggles. By claiming that they are part of the worldwide Anglican Communion, which, citing Lambeth 1.10 (1998), they argue supports their position, they become not just a beleaguered and oppressed minority, but also part of the global majority, the Anglican Mainstream, or representatives of, true, Orthodox Anglicanism (Bishop John, Bishop Henry).

While Anglicanism has long had, in addition to its Episcopal structure, its articles and creeds, conservative dissidents worldwide have recently constructed a new category, which effectively operates as a new form of capital: "Anglican Orthodoxy". "Orthodoxy" as a new form of religious capital serves to suture together conservative Anglo-Catholics and conservative Evangelicals within the church, excluding those who do not possess sufficient orthodoxy as illegitimate Anglicans, and illegitimate Christians both (on the new category of Anglican Orthodoxy, see Authors). As such, 'liberal' bishops have come to be defined both by conservative overseas bishops, as well as priests and laypeople in their own diocese, as illegitimate, and not possessing, to use Bourdieu's phrase, the 'goods of salvation'. It becomes a religiously imperative to contest such bishops and their authority, for 'Orthodox' bishops to commit incursions against their dioceses, and, not insignificantly, for the local faithful to sue them for the right to succeed from their dioceses with church property in hand. Such claims to being the true bearers of historic, orthodox Anglicanism are not, of course, universally accepted, not least significantly, by the courts (see, Bentley v. Anglican Synod of the Diocese of New Westminster, 2009). Significantly, in our interviews, we have found that aconservative moral position on homosexuality serves as the primary marker of Anglican Orthodoxy, though it is an item that does not appear in the classical Anglican formulations of doctrine. Some bishops find themselves labelled as liberals, on account of their position on this matter, despite not seeing themselves as 'liberals' in many other ways (Bishop Kevin). 
If local conservative dissidents in North America have used overseas bishops to support their cause and give them a measure of legitimacy in the wider Anglican Church, it is equally clear that some bishops have used local conflicts in dioceses well beyond their jurisdiction for their own purposes. While Philip Jenkins is right to suggest that the shifting demographics in the global Anglican Communion is vital for understanding the conflict, it is not true that changing demographics automatically results in changing power relations. For Bishop Mark (among other bishops), these power struggles are partly related to geopolitical re-configurations:

Well, I think that in any institution, whether in the church or not, there are always bids for power, in any court, and by that I mean in monarchical societies, or even republican societies, whatever.... Everybody who is in power has a group of people around him or her, and they constitute a court and up to now, it's been relatively clear that the centre of power in the Anglican Communion has been the Archbishop of Canterbury, and the office of that Archbishop. And that has in unspoken ways has enabled the Anglican Communion to function. And now there are other people in other parts of the world who have started to say, now hold on, the British Empire is gone, we seem to have more Anglicans than England does, and so the power has shifted to us, so we should take power. I think there are bids for power going on, that are across the Anglican Communion. The bid is to say that we and we alone know what the Anglican Church is (Bishop Mark).

The strong position taking on a matter that the Nigerian, Ugandan, Rwandan and Kenyan Anglican Churches say is only indirectly relevant in their contexts can also be seen as a means of increasing the profile of leaders in accordance with the size of their flock. Other leaders, such as the Evangelical Archbishop of Sydney are, it is often suggested, using the conflict 
over homosexuality as a means of gathering allies for their particular struggles to reform the church (Bishop Luke). Likewise, the Archbishop of the Southern Cone (unlike the Central Africa, not an area with an Anglican demographic boom) has increased his profile by taking under his wing conservative dissidents in Canada and in the USA, as well as in neighbouring Brazil. Such 'incursions' have brought with it criticism and condemnation, but it is probably part of the reason that Archbishop Venables has gone from being the head of an insignificant province to being an important figure in the Anglican Communion; he was recently placed at number 7 on a recent Sunday Telegraph listing of the 'Top 50 Influential Anglicans', coming immediately after the retired Archbishop of Cape Town, Desmond Tutu (13 July 2008).

If Episcopal authority is a key form of capital in the organisation of the Anglican Communion, no bishop has more of it than the Archbishop of Canterbury. The leaders of GAFCON have made known their view of this first of the Instruments of Unity in "The Jerusalem Statement": 'While acknowledging the nature of Canterbury as an historic see, we do not accept that Anglican identity is determined necessarily through recognition by the Archbishop of Canterbury' (“Jerusalem”). Somewhat surprisingly, as we've conducted interviews with high level leaders in the church, and even before the GAFCON declaration, the question of the 'Polish Pope'-John Paul II having been the first non-Italian Pope in almost 500 years — has been raised on numerous occasions. While acknowledging the traditional role of the Bishop of Canterbury as the Primate of All England, some, even within the UK have begun to express discomfort or reservations about why it should necessarily be the occupant of the See of Canturbury that should be the figurehead of the Anglican Communion. More problematic — for an Established Church—is the suggestion that if Canterbury should continue to play this role, the rest of communion should have a say in who occupies that See. There might not be a shortage of people who would see themselves as potential candidates for the position, particularly within the GAFCON leadership. 


\section{Conclusion}

Pierre Bourdieu's sociology of religion has proved itself useful as we have endeavoured to make sense of the current controversy in the Anglican Communion. Bourdieu's understanding of the religious field needs to be understood in less parochial terms, encompassing transnational fields, and making less comprehensive assessment of the effectiveness of the monopoly mechanism. Even in times of relative stability, we would argue, the monopoly over the goods of salvation are far from total, and lay people can and do manipulate religious symbols that allow them to change the nature of the institution. In times of crisis, such as that in which we find the Anglican Communion at this historic juncture, it is clear that the hierarchies, and the forms of religious capital which support them, become considerably less than stable. The outcome of the current crisis is far from clear.

\section{References}

Ammerman, Nancy Tatom. Baptist Battles: Social Change and Religious Conflict in the

Southern Baptist Convention New Brunswick: Rutgers University Press, 1990.

Bates, Stephen. A Church at War: Anglicans and Homosexuality London: Hodder and Staughton, 2005.

Bentley v. Anglican Synod of the Diocese of New Westminster BCSC 1608, 2009.

Birlinerblau, Jacques. "Towards a Sociology of Heresy, Orthodoxy and Doxa" History of Religions 40 (2001): 327-351. 
Bourdieu, Pierre, and Monique de Saint Martin. “La Sainte Famille: L’épiscopat Francais dans la Champ du Pouvoir." Actes de la Recherche en Sciences Sociales 44.1 (1982): 2-53.

Bourdieu, Pierre. "La dissolution du religieux.” In his Choses Dites Paris: Les Éditions de Minuit, 1987: 117-123

---, “Sociologues de la croyance et croyances de sociologies.” In his Choses Dites Paris: Les Éditions de Minuit, 1987: 106-111

---, “Legitimation and Structured Interests in Max Weber's Sociology of Religion" in Max Weber: Rationality and Modernity. Ed. Sam Whimster and Scott Lash. London: Allen and Unwin, 1987: 119-136

---, “Genesis and Structure of the Religious Field” Comparative Social Research 13 (1991): $1-44$.

---, Acts of Resistance New York: The New Press, 1998.

Bourdieu, Pierre, and Loïc Wacquant. An Invitation to Reflexive Sociology Chicago: University of Chicago Press, 1992.

---, “The Cunning of Imperialist Reason" in Loïc Wacquant Pierre Bourdieu and Democratic Politics Cambridge: Polity Press, 2004. 
Chaves, Mark. Ordaining Women: Culture and Conflict in Religious Organizations

Cambridge MA: Harvard University Press, 1997.

Dianteill, Erwan. "Pierre Bourdieu and the Sociology of Religion: a Central and Peripheral Concern" Theory and Society 32 (2003): 529-549.

Dillon, Michele. "Pierre Bourdieu, Religion, and Cultural Production" Cultural Studies/Critical Methodologies 1.4 (2003): 411-429.

Engler, Stephen. "Modern Times: Religion, Consecration and the State in Bourdieu" Cultural Studies 17.3/4 (2003): 445-467.

Flanagan, Kieran. "Sociology into Theology: The Unacceptable Leap" Theory, Culture \& Society 25.7-8 (2008): 236-261.

Global African Futures Conference "The Jerusalem Declaration", 2008.

<http://www.gafcon.org/news/gafcon_final_statement/>

Hassett, Miranda. Anglican Communion in Crisis: How Episcopal Dissidents and their African Allies Are Reshaping Anglicanism. Princeton: Princeton University Press, 2007.

Jenkins, Philip. The Next Christendom: The Coming of Global Christianity. New York: Oxford University Press, 2007. 
Karakayali, Nedim, "Reading Bourdieu with Adorno: The Limits of Critical Theory and Reflexive Sociology.” Sociology 38.2 (2004): 351-368.

Kniss, Fred, Disquiet in the Land: Cultural Conflict in American Mennonite Communities. New Brunswick: Rutgers University Press, 1997.

Rey, Terry. Bourdieu on Religion. Imposing Faith and Legitimacy. London: Equinox, 2007.

Roy, Olivier. Globalised Islam: The Search for a New Ummah. London: C Hurst \& Co Publishers, 2004.

Verter, Bradford. "Spiritual Capital: Theorizing Religion with Bourdieu Against Bourdieu." Sociological Theory 21.2 (2003): 150-174.

Wilde, Melissa. Vatican II: A Sociological Analysis of Religious Change. Princeton: Princeton University Press, 2007.

Wood, Matthew, and Christopher Bunn. "Strategy in a Religious Network: A Bourdieuian Critique of the Sociology of Spirituality.” Sociology 32.2 (2009): 286-303.

\footnotetext{
${ }^{1}$ The motion passed 526 in favour, 70 Opposed, 45 Abstentions noted (with almost 100 votes unaccounted for).

${ }^{2}$ All names used in interviews in this paper are pseudonyms, and primates, metropolitans and Archbishops are referred to simply as bishops. Because these are individuals who are well known to a large public, for reasons of confidentiality, we are unable to identify from which provinces different bishops come, or the number coming from each province as they appear in our sample.
} 